\title{
Eco-friendly management of late blight of potato- A review
}

\author{
Shailbala ${ }^{1}$ and Amarendra Kumar ${ }^{2 *}$ \\ ${ }^{1}$ Department of Plant Pathology, G. B. Pant University of Agriculture and Technology, Pantnagar-263145 \\ (Uttarakhand), INDIA \\ ${ }^{2}$ Department of Plant Pathology, Bihar Agricultural University, Sabour, Bhagalpur-813210 (Bihar), INDIA \\ *Corresponding author. E-mail: kumaramar05@gmail.com
}

Received: April 12, 2016; Revised received: January 20, 2017; Accepted: April 24, 2017

Abstract: Late blight of potato caused by fungus Phytophthora infestans responsible for Irish famine in the year 1845 , is one of the most dramatic episode caused by plant pathogen in human history. One million people died due to famine in Ireland. So eco-friendly management of potato late blight disease is a necessary goal to be accomplished. During last many years, management strategies solely relied upon the application of fungicides due to rapid development of late blight epidemics. However, indiscriminate use of fungicide posesses a serious threat to the environment and human health. It is also responsible for built up of resistance in the pathogen and have adverse effect on beneficial organisms such as nitrogen fixers, resident antagonism and mycorrhizal fungi. So to minimize the fungicide use, eco-friendly means for late blight management are required on a priority basis. In recent years, significant changes in isolates of late blight fungus have been recorded including changes in aggressiveness to the crop also. Since, late blight is a community disease so, effective eco-friendly management must be adopted by the all producers, farmers, gardeners and growers with the help of government agencies, extension specialist and crop consultants etc. The strategy to control late blight is the prevention of establishment of Phytophthora infestans in potato crop. In this context, disease management by cultural practices is the first line of defense while forecasting system, physiological strategies, biological control, host plant resistance and bio-technological approach are essential for efficient, effective and eco-friendly management of late blight of potato.

Keywords: Potato, Late blight, Phytophthora infestans, Disease, Bio-agents, Forecasting

\section{INTRODUCTION}

Late blight caused by the oomycete pathogen Phytophthora infestans, disease of major concern all over the world is costing huge losses every year in potato (Kumaon et al., 2001). Reports of complete field destruction due to late blight epidemics are relatively common. The fungus is responsible for global annual crop loss of US \$ 12 billion. Yield loss due to late blight in India varies from year to year and range from 20-75 \% (Sundaresha et al., 2015).

The pathogen $P$. infestans is highly variable and has sophisticated weaponry including effectors molecules coded by avirulence genes that allow rapid infection and host tissue colonization (Kamoun and Smart, 2005). Once inside host tissue, a complex set of compounds such as metallopeptidase, cutinase and other protein with no identification function required for cell killing and nutrient uptake are promptly activated (Lee et al., 2006). There are ten avirulence proteins are known to be involved in pathogenesis and act as effectors that are delivered inside the plant cell (Haldar et al., 2006). These protease inhibitors produce by the pathogen to disturb the defence mechanism of the host plant. New class of protease inhibitors were described in P. infestans (Tian et al., 2007). For more than a dec- ade, controlling late blight has become increasingly demanding because of the emergence of new strains of the pathogen, some new strains are known to be more aggressive and resistant to the fungicide metalaxyl (Daayf et al., 2001). Moreover, indiscriminate use of systemic fungicides especially metalaxyl (ridomil) provides chance to develop resistant strain of the fungus has been reported from home and abroad (Singh, 2000). A new sexually reproducing potato late blight $(P$. infestans) population characterised by early oospore-derived epidemics is one of the most severe threats to organic potato production (Lehtinen and Hannukkala, 2004).

Innovative and effective control measures are needed if fungicide use is to be reduced or eliminated as in case of organic potato production. The term alternative can have multiple meanings and its interpretation varies accordingly. In this context, Cultural control is the first line of defence which includes change in date of planting, intercropping, nutrient management, irrigation management etc. For eco-friendly disease management, forecasting system plays important role so that preventive measures can be taken up if there is likelihood of disease appearance. Physiological strategies i.e. escape and resistance are very important to 
cope up with disease. In general, due to the different modes of actions (i.e. antagonistic effects or induction of plant defence mechanisms), the use of microorganisms as biological control agents has a definite potential. Currently potato varieties with fully late blight resistance are under serious study in breeding programme. Thus, they may represent an interesting tool for the development of novel concepts in disease management. Even biotechnology is also being employed in the pursuit of late blight resistance. Fully resistant genetically engineered strains are expected soon. In this review, we will try to use eco-friendly approaches that include non-fungicidal strategies such as cultural method, forecasting system, physiological strategies, biological control, host plant resistance and bio-technological approach for management of late blight disease.

Pathogen: In 1861, Anton de Bary experimentally established that the fungus was the cause of plant disease known as late blight of potato, a disease that closely resembles the downy mildew. In 1875, de Bary studied it in detail and gave name the pathogen to Phytophthora infestans which means infectious plant destroyer (Turner, 2005). The fungus have special feature of an indeterminate sympodial sporangiophore with ovoid, detachable and papillate sporangia (de Bary, 1876; Widmark, 2010). Anton de Bery also showed that late disease could easily appear on fungal spore dusted on potato plants. He also described the motile zoospore and pathogen's life cycle (Widmark, 2010). Phytophthora belongs to the kingdom Stramenopila, a group of micro-organism that is closely related to brown algae, golden brown algae and diatoms (Forster et al., 1990; Dick, 2001), phylum-Oomycetes, orderPernosporales, family-Pythiaceae. Phytophthora infestans is also considered as model organism for oomycetes, a distant lineage of fungus like eukaryotes (Kamoun and Nusbaum, 2009).

Pathogen variability: Important aspects of monitoring population structure of $P$. infestans should be considered for thorough analysis and proper development of alternative procedures aiming at controlling the late blight in potato. Even it has been on the agenda of scientific community and techniques have become available. Biological markers including mating types, race pattern, metalaxyl sensitivity and ploidy are the potential means for monitoring variability in $P$. infestans. The occurrence of sexual reproduction also affects the population dynamics of the pathogen. Two contrasting scenarios for genetic structure of population of $P$. infestans can be envisioned: (1) A panmictic population is comprised of a large number of distinct genotypes of $P$. infestans and (2) A clonal population structure with limited number of clonal lineages (Eduardo et al., 2007). High genotypic diversity of pathogen can provide greater potential for local adaptation to the changing environment which makes disease management more difficult (Sujkowski et al., 1994). In areas where population is clonal, the risk of new diversity being introduced grows as seed trade becomes more globalized.

Physiological races: Fungus $P$. infestans is consider as highly variable due to the frequent appearance of its new pathogenic virulent types in field and often observed in the laboratory. Giddings and Berg (1919) and Berg (1926) were pioneers in detecting variations in the $P$. infestans populations. After almost seven years of introduction of resistant hybrids/cultivars having $\mathrm{R}$ genes, pathological specializations (races) within potato isolates were reported by Schick (1932). In 1958, race 0 and race 1 were prevalent, the former being predominant in North- western hills. In 1965, race 3 and 4 appeared for first time (Dutt, 1965). In 1969, race 0 was still common race $(58 \%)$ but frequency of race 1 increased considerably (42\%) over the years. Two gene complex races recorded in 1971 attacked the late blight resistant varieties i.e. Kufri Jyoti, K. Jeeevan (Phadtare et al., 1973). Thirteen new races were identified by 1975 in Shimla hills. By 1978, the complex races started appearing more frequently. Absence of race 0 and predominance of race $3,4,7,8,10,11$ indicated the shift in the virulence of $P$. infestans was almost complete (Bhattacharyya and Singh, 1986). In Northern plains, 31 races were recorded (CPRI, 1981 and 1987). Complex races were more dominant in 1998 in Shimla hills (CPRI, 1999) and different locations of Pantnagar (Shanmugam, 2001). However, universal appearance of races or, at least their detection, did not occur until resistance genes from Solanum demissum were transferred to commercial potato species, $S$. tuberosum. Since then, race spectrum in different countries/regions has been monitored regularly. Virulence to all major resistance genes was recorded (Guo et al., 2009).

One hundred and twenty one races were reported from Mexico (Rivera-Pena, 1995). Thirty eight physiological races were identified among 60 potato and tomato isolates from different Italian regions (Cristinzio et al., 1998). In India, the racial complexity has reached its zenith and presently most complex races (10-11 gene complex) are prevalent in most potato growing regions (CPRI, 2013).

Mating types: $P$. infestans is heterothallic and requires two mating types for sexual reproduction. Prior to 1984 the A2 mating type was restricted to Mexico and Andean mountains. First report of A2 mating type outside Mexico was from Switzerland (Hohl and Iselin, 1984). Subsequently, A2 mating type was detected in other countries too. Singh et al., (1994) reported the presence of A2 mating type in India. Occurrence of A2 mating type in different parts of the world is considered to be due to a second migration of $P$. infestans from Mexico (Fry et al., 1999), the first being from Europe and America during the historical potato 
famine around the year 1845 .

In India, A2 mating type has stabilized in temperate hills while the A1 is dominating in sub-tropical plains (Singh et al., 2005; CPRI, 2013). When the two mating types grow adjacently, the female hypha grows through the young antheridium (male reproductive cell) and develops into a globose oogonium (female reproductive cell) above the antheridium. The antheridium then fertilizes the oogonium, which develops into a thick-walled and hardy oospore (Tsedaley, 2014).

Oospores germinate by means of a germ tube that produces a sporangium, although at times the germ tube grows directly into the mycelium. Sporangia germinate almost entirely by releasing three to eight zoospores at temperatures up to 12 or $15^{\circ} \mathrm{C}$, whereas above $15^{\circ} \mathrm{C}$ temperature, sporangia may germinate directly by producing a germ tube (Agrios, 2005). The new strains of the pathogen have been found to be more aggressive than the old population (Fry et al., 1999). Recent work has indicated that the new $P$. infestans clones, especially the US-8 and US-14 genotypes, are more aggressive (Kirk et al., 2009). Migration and sexual recombination can play an important role in enhancing genetic diversity in $P$. infestans. An increasing severity of late blight, a shift in pathogen population toward increased specific virulence and an increased tolerance to metalaxyl has been recorded in past three decades in the north western plains of India (Arora, 2008).

Metalaxyl resistance: Metalaxyl, a phenylamide group of systemic fungicide, acts by interference in RNA synthesis by inhibition of rRNA polymerase or both RNA and DNA synthesis. Due to its site specific nature, it becomes more prone to development of resistance in the pathogen. Fungicide resistant isolates were detected in oomycetous fungi soon after the introduction of these fungicides as single products on various crops including $P$. infestans in Europe, the Middle East and in the Moscow region at the end of 1980's. In India, resistance to metalaxyl in P. infestans wild population was first observed in Nilgiri hills of South India in 1989.

Metalaxyl resistant strains appeared towards the end of summer crop season and their frequency increased to 13 per cent in autumn season. Fungicide mixture (Metalaxyl + Mancozeb) could best be used from early to mid summer and must be avoided toward the end of summer season or during the autumn season when the resistant isolates were more frequent in the region (Arora et al., 1992). Since then the monitoring for metalaxyl resistance is being done regularly. A few strategies have been identified to manage the problem of resistance against metalaxyl in $P$. infestans. These include withdrawal of straight product and introduction of mixture with contact residual fungicides, regulation of number of sprays and their use early in the season, etc (Arora et al, 2014).

Disease symptoms: Disease symptoms are characterized as circular or irregular water soaked lesions on leaves. Initially, these lesions are localized on tips and margins of the leaves, sometimes surrounded by pale yellowish border. Lesions develop very fast into brown to black necrotic spots and cover entire leaf surface. These lesions also appear on the stem. Whole crop gives blighted appearance and may destroy under high disease severity. Under favourable weather condition (cool and high wetness period) white, fluffy fungal growth may be visible primarily on the underside of the leaf which is the main distinguishing feature of late blight disease. Fry et al., (2001) also recorded reddish brown, dry, hard and granular lesions in potato tubers. These lesions in affected tubers spread irregularly from the outer surface $(3 \mathrm{~mm})$ to deep $(10 \mathrm{~mm})$ in pulp. Disease appears on stem as grayish brown to black elongated lesions. Under high moisture and low temperature conditions, it sporulate profusely and destroy entire green top of the plant.

Epidemiology: Infected seed tubers put into cold storage are responsible for perpetuation of fungal spores and mycelial growth from one season to another. 0.01 $\%$ to $3.0 \%$ of tuber infection is sufficient to initiate and develop late blight epidemic in the next cropping season (Bhattacharyya et al., 1990). Forbes and Landeo (2006) also reported that several wild solanaceous plants carry the pathogen Phytophthora infestans. Ideal condition for late blight infection and development are night temperature $10-16^{0} \mathrm{C}$ with light rain, fog, next day temperature ranged from $13^{0} \mathrm{C}$ to $16^{0} \mathrm{C}$ with high relative humidity (Kirk, 2009; Kirk et al., 2013). Congenial conditions for appearance and build up of late blight disease includes $18^{0}$ to $22^{0} \mathrm{C}$ temperature and 80-100\% relative humidity (Fry et al., 2001).

Production of sporangia and their germination are an important key stages in the life cycle of pathogen which lead to infection, are mainly dependent on high humidity so humidity is always consider as key factor for development of disease. High relative humidity or free moisture is very important for prolonged survival of sporangia. Sporangia germinated by single germ tube at low temperature $\left(13^{0}-21^{0} \mathrm{C}\right)$ and at high temperature $\left(30^{0} \mathrm{C}\right)$ fungus slow down or stop the growth in the field. According to Agrios (2005) at high relative humidity (near $100 \% \mathrm{RH}$ ) fungus restart the sporulation. The fungal spores are carried by air currents and rain from infected plant to healthy plants and disease cycle restarts. Several workers also reported that the pathogen $P$. infestans has been carried into field by air currents (Martin et al., 1994; Kirk et al., 2013). Once fungal pathogen establish in the field, it shows rapid increase of disease and complete reproduction cycles in a season (Tsedaley, 2014).

Whenever sporangia come in contact with tuber right 
from tuberization till harvesting, potato tubers may get infected. Generally, infection takes place when sporangia washed and fall down from lesion to soil and then through soil to tubers. During tuber enlargement period, contact between tubers and sporangia may be more because it develop cracks in the soil and sporangia become readily accessible and infection can be noticed on developing on mature tubers. Temperatures more than $18^{0} \mathrm{C}$ suppress the infection in tubers. Fry (1998) observed that sporangia can survive for a weeks or few days in soil so tuber may infected for some period of time even after infection are no longer producing sporangia. The fungus can survive in living tissues, infected seed tubers, infected tubers in cull piles, unharvested and volunteer potatoes left in the ground (Shinners et al., 2009). The fungus can also survive on other solanaceous plant or weed and in the soil (Kirk et al., 2013). Wind, splashed rain, mechanical transport and animals etc are responsible for spread of sporangia from one field to another produced by fungus $P$. infestans (Martin et al., 1994; Kirk et al, 2013). After few days of infection, new sporangiophore emerges from stomata of leaves and gives rise to numerous sporangia. Sporangia germinate either directly by germ tube or indirectly by liberating zoospores. Germ tube enters through stomata and mycelium grows between the cell and send long curled haustoria into the cell. Agrios (2005) concluded that as disease develop under favourable condition, the already established lesions increase in size and cover the entire surface of leaves, new ones lesion also develop, kill the foliage and finally reduce the tuber yield.

During wet weather when sporangia washed away from leaves and reached into the soil, the second phase of disease starts in the field. Zoospores develop and penetrate the tubers through wounds, mechanical injury or through lenticels. Mycelium grows profusely between the cells and send haustoria into the cells of tubers. During harvesting, tubers got contaminated due to presence of living sporangia in the soil or on diseased foliage and become infected. The excessive humidity (near $100 \%$ ) coupled with suitable temperature ranged from $15^{\circ} \mathrm{C}$ to $25^{\circ} \mathrm{C}$ important for disease development (Agrios, 2005). Generally. pathogen survives in infected tubers in areas where sexual reproduction does not take place. According to FernandezPavia et al., 2004 fungus may survive in soil for many years in areas where viable oospore or sexual reproduction occurs.

Disease management: The main obstacle associated with late blight management is emergence of new strain of Phytophthora infestans which always create a major challenge to potato growers. So management of late blight disease through integration of several options i.e. cultural control, disease forecasting system, physiological strategies, biological control, host plant resistance and bio-technological approaches can help to overcome this major challenge by avoiding environmental hazards by fungicides.

Cultural control: Garrett and Dendy, 2001 observed that reduction in pathogen populations by lower down the survival, dispersal and reproduction of pathogen are main principle of cultural control which can be achieve by change in date of planting, intercropping, nutrient management and irrigation management.

Change in date of planting: Change in normal planting time not only gave maximum tuber yield but also reduced 10-15\% late blight disease (Desh Raj et al., 1997). Garg et al., (1999) reported that delay in planting gave less number of seed tubers. According to Shailbala and Pundhir (2006) less late blight disease incidence were noticed in early planted crop. This may be due to significantly higher population of phylloplane fungi in early planted crop and showed less disease pressure (Shailbala and Pundhir, 2007). Change in planting date affect the crop's susceptibility towards disease and its potential to attack and infect adjacent crops (Hospers-Brands et al., 2008).

Intercropping: Intercropping of potato with garlic crop in 1:3 ratio gave the best results for management of late blight of potato crop and become as potential intercropped crop due to chemical secreted from root of the garlic affect the late blight disease (Kassa and Sommartya, 2006). Shailbala and Pundhir (2007) reported that intercropping of potato cultivar Kufri Chipsona with mustard cultivar Divya showed less disease incidence, less infection rate, high tuber yield and finally more return. Bouws and Finckh (2008) concluded that potato intercropped with cereals and clover grass may reduce the late blight disease pressure.

Nutrient management: To get high tuber yield and quality tubers, nutrient dose in balanced proportion is primary requirement for potato crop (Imas and Bansal, 1999). Always avoid excessive use of nitrogen to the potato crop produce lush green, large canopy which maintain excessive moisture in between the crop and increase the risk of late blight disease. Even make crop more susceptible to infection. Marschner, (1995) reported that optimum dose of potassium fertilizer lower down the late blight incidence.

Irrigation management: Potato tubers are sown in ridges to avoid the contact of potato tubers to excessive moisture which may lead to rotting etc. Irrigation plays very important role to manage the late blight disease. If soil moisture is more than field capacity for atleast 24 hours followed by $\geq 8 \mathrm{~mm}$ rainfall results tuber infection by pathogen Phytophthora infestans (Adams and Stevensen, 1990). To minimize the duration of leaf wetness, irrigation management is very important. During morning hours foliage become wet due to presence of dew. Irrigate the crop during morning hours so that irrigation coincides with leaf wetness period just because of dew. Alternatively irrigate the crop during day time because foliage goes through drying period. Very 
long wetness period is responsible to increase late blight risk. If possible drip irrigation can also be practiced to minimize irrigation applied leaf wetness.

Disease forecasting system: More precise and timely environmental monitoring, weather forecasting, technology transfer network at state, zonal and national level are main factors for disease forecasting. Different late blight forecasting models utilized in many potato growing areas of world which adequately and efficiently forecast the first appearance of disease in particular area. Late blight forecasting models are area specific due to variation in weather condition. Van Everdingen (1926) developed Dutch rules by using weather condition to forecast potato late blight. Temperature, dew period, cloudiness and rainfall were used to predict initial appearance of late blight disease in Holland. Bourke (1953) developed Irish rules for Irish peoples to forecast the disease and concluded that atleast 12 hours of wetness period, air temperature not less than $10^{\circ} \mathrm{C}$ and $90 \% \mathrm{RH}$ are required by sporangia of Phytophthora infestans for germination and infection. According to Smith (1956), minimum temperature $10^{\circ} \mathrm{C}$ for two consecutive days and atleast 11 hours of $\mathrm{RH} \geq 90 \%$ is favourable for disease development. Accurate forecasting can be possible to those diseases which are sporodic in nature (Bourke, 1970). Austin Bourke used synoptic weather chart as a tool for late blight forecasting (Bourke, 1970; Keane, 1995). Daily maximum temperature $17^{0}-24^{0} \mathrm{C}$, minimum temperature $\geq 10^{\circ} \mathrm{C}, \mathrm{RH}$ at noon $\geq 75 \%$, daily rainfall $\geq 0.1 \mathrm{~mm}$ are important factor to assess the risk of potato late blight disease (Forsund, 1983). Sharma (2000) developed late blight forecasting model for North Western region of India especially Jalandhar and concluded that disease development was positively correlated with maximum $\mathrm{RH}$, rainfall, dew and cloudy days. Henshall et al., 2006 developed Shtienberg model for late blight risk in which they combined inoculum index with infection index to develop 0-3 late blight risk index corresponding to nil (0), light (1), moderate (2) and severe (3) risk of disease.

Favourable day's model: Daily rainfall, maximum and minimum temperature are important features of favourable day's model. For different potato growing areas, thermohydrograph were prepared by Dutt (1964) which indicate blight periods of that particular area. If 7 days moving precipitation average $30 \mathrm{~mm}$ for Shimla, $28.9 \mathrm{~mm}$ for Ooctamound and $38.5 \mathrm{~mm}$ for Shillong with mean temperature $\leq 23.9^{\circ} \mathrm{C}$ for 7 consecutive days or hourly temperature ranged from $10^{\circ}-20^{\circ} \mathrm{C}$ with $\geq 80 \%$ RH for 18 hours for two consecutive days, late blight would appear within 3 weeks (Bhattacharya et al., 1983). Singh et al., 2000 developed, a computerized forecasting system known as Jhulsacast against late blight of potato for Western Uttar Pradesh for rainy as well as non-rainy years, in which model 1 for rainy year includes measurable rain
(0.1-0.5 mm) for a minimum of 2 consecutive days, 5day moving $>85 \%$ relative humidity period $\geq 50$ hours and 5-day moving congenial temperature $\left(7.2-26.6^{\circ} \mathrm{C}\right)$ period $\geq 120$ hours while model 2 for non-rainy year includes 7 -day moving $>85 \%$ relative humidity period $\geq 60$ hours and 7-day moving congenial temperature $\left(7.2-26.6{ }^{0} \mathrm{C}\right)$ period $\geq 120$ hours.

Severity value model: The first appearance of late blight and periods of late blight favorable weather can be predicted using relative humidity, rainfall and temperature data collected from an electronic weather monitor or a hygrothermograph. The weather data is converted into units called severity values (SV) for the purpose of predicting late blight outbreaks. Late blight is first expected to appear within 12 weeks after $18 \mathrm{SV}$ have accumulated. Fungicide applications to protect potatoes should be initiated as soon as possible after $18 \mathrm{SV}$ have accumulated. The Wallin system was developed by Jack R. Wallin (1962) in Midwestern United States which interprets the epidemiologic consequences of extended periods of high relative humidity and temperature during those humid periods. Late blight is forecast to occur 7 to 14 days after 18 severity value have accumulated.

Negative prognosis model: Ullrich and Schrodter (1966) gave negative prognosis model uses measurement of temperature, relative humidity and rainfall to predict when late blight epidemics are not likely to occur. It has been used to predict the timing of the first prophylactic treatment in Germany. Daily and accumulated risk values over a week are calculated starting at crop emergence. Disease is expected when accumulated risk value has exceeded the threshold of 150 .

Model with spatial dynamics: Minogue and Fry (1983) modelled the spatial dynamics of potato late blight and found that blight foci expand with constant velocity determined by host resistance and fungicide use. Paysour and Fry (1983) used a model to calculate the level of inter plot interference in experiment with potato late blight. Ferrandino (1989) also made spatial model of potato late blight used to examine the relation between spatial distribution of disease and yield loss.

Mathematical model on late blight disease: Johnson et al., (1996) developed two discriminant function and two logistic regression models to forecast outbreak of late blight in South Central area of Washington State. The first discriminant function uses the following variables: late blight out break during the preceding year $\left(Y_{p}=0=n o ; Y_{p}=1=y e s\right)$, number of days with rains greater than or equal to $0.25 \mathrm{~mm}$ during the month of April and May and total precipitation during May when daily minimum temperature was more or equal to $5^{0} \mathrm{C}\left(\mathrm{P}_{\mathrm{m}}\right)$. The second discriminant function uses $Y_{p}, R_{a m}$ and number of days with rain more or equal to $0.25 \mathrm{~mm}$ during July and August.

Simulation model: Waggoner (1968) presented the 
first computer simulation model for potato late blight in which the effect of environmental condition on the resistance component was extensively modelled. A procedure for timely fungicide application to suppress potato late blight was developed by using two simulation models. The first model stimulated the effect of environment, fungicide and host resistance on $P$. infestans in potato foliage (Bruhn and Fry, 1981). The second model described fungicide deposition and subsequent re-distribution on potato foliage (Bruhn and Fry, 1982 a, b). Fry et al. (1983) described forecasting model which was derived from two simulation model. One model described weather effects on fungicide distribution and amount while second model described effects of host resistance and weather on development of $P$. infestans.

Van Oijen (1992) used simulation model to evaluate the importance of different host resistance components. Andrare-Piedra et al. (2005) discovered the domain over which a validated model may be properly used, was illustrated with LATEBLIGHT, a mathematical model that stimulates the effect of weather, host growth, resistance and fungicide use on asexual development and growth of $P$. infestans on potato foliage. Forbes et al., (2008) developed most recent version LB2004 which has been validated in the highlands tropics and several other countries.

Decision support system / expert system: Decision support system increases the efficacy of control strategies without increasing disease risk in potato plant. Krause and colleagues at Pennsylvania State University (Krause et al., 1975) developed a computerized forecast model known as BLITECAST. PhytoPRE is a computer based information and decision support system for potato late blight in Switzerland which consists of an epidemiological forecast model, a set of decision rules and an information system (Forrer et al., 1993).

PROGEB forecasting model have PHYTEB as one of their components which forecasts $P$. infestans and stimulates symptomatic stages of the host (latent period, pre-infection, number of infection, amount of dead tissue). PHYTEB consist of two sub models SIMPHYT-1 and SIMPHYT-2 and forecast the beginning of epidemic 7-10 days ahead (Gutsche, 1993). SIMBLIGHT 1 model had been developed which requires temperature, relative humidity, information on soil moisture, crop prevalence and cultivar susceptibility (Benno kleinhenz et al., 2007). Wharton et al., (2008) developed a web-based expert system to help potato growers in Michigan regarding control measures to mitigate the risk of potato late blight disease development. Fry et al., (2015) also discussed the BlightPro, a decision support system developed to aid the management of potato late blight in USA. For Indian condition Indoblightcast were developed for managing the disease in a cost effective and environmental friendly manner (Govindakrishnan et al., 2015)

Based on agro advisory system, Pande et al., (2009) used mobile phone to forecast late blight disease in which actual late blight queries received from farmers were compared and validated with cumulative composite rise index taken from existing forecasting models. System based on diagnostic approaches was incorporated with forecasting models.

Physiological strategies: Every crop plant has potential to develop physiological strategies to deal with diseases. These physiological strategies are escape, resistance, tolerance and recovery. The fungus $P h y$ tophthora infestans attack and affect the crop resulting reduction of the leaf area which directly lower down the photosynthesis process and reduce the crop capacity to produce photosynthetic assimilates require for growth and maintenance of haulm and for tuber bulking.

The pathogen directly infected the tuber and reduces the yield \& market value of tubers. These infested tubers put for storage in cold storage serve as important source of inoculum. An infected crop also serves as source of inoculum which is really unacceptable in area where potato crop is grown in high proportion. Due to these reasons, two physiological strategies i.e. escape and resistance work against late blight disease in potato crop.

Struik (2010) worked on physiological strategies to cope with disease based on escape and resistance. Escape strategy includes advance or change the entire crop cycle so at the time of pathogen attack, the crop will become mature enough to cope with disease. If potato crop is planted in early october in sub-tropical, it may escape blight attack. The advancing of crop cycle can be done by early planting of crop, planting larger seed tubers etc (Struik and Wiersema, 1999). Disease can be escape by accelerating the early canopy growth without advancing tuber bulking. This may be possible through agronomic practices such as extra nitrogen application (which might delay tuber bulking up to some extent). Advancement in tuber bulking without advancing canopy development can also be one of the escape strategies. This can be achieving by manipulating the physiological age of the seed tubers (Struik and Wiersema, 1999). Accelerate the tuber bulking without advancing it through chemical treatment of foliage may be other escape strategy.

Other physiological strategies to cope with late blight disease through resistance include strengthening the race non-specific resistance which results delay in initial infestation and slower development of disease. Race non-specific resistance against late blight is strongly associated with foliage maturity type (Visker et al., 2003a, 2003b, 2004, 2005). The other resistance strategy is influencing the micro-environment around the basal leave (most sensitive plant parts) which will slow down the development of late blight epidemic and 
inhibit first infestation. Planting pattern, row to row distance, seed treatment, seed tuber size etc will make such micro-environment which is not conducive to infection by the pathogen.

Biological control: Management of highly destructive disease such as late blight of potato is slightly difficult due to rapid establishment of infection and explosive disease development. So, little information is available regarding biological control as potential alternative against late blight disease. In biological control, living micro-organism or abiotic products provide disease protection through production of antibiotics, competition for food and space, induced plant resistance etc. Various fungi, bacteria and different compost extracts were tested against Phytophthora infestans in potato crop (Ghorbani et al., 2005) and reports revealed that extract made from different compost feed stocks of different age suppressed blight infection in leaflets (Lamsal et al., 2013). Daayf et al. (2003) also studied on biological control of potato late blight by detached leave method, whole planting testing system and in vitro. Shailbala and Pundhir, 2008 observed that Trichoderma (formulation) @ $10 \mathrm{~g} / 1$ and Pseudomonas (formulation)@10 g/l showed antagonistic behaviour and gave the best results against late blight disease.

Application of Xenorhabdus spp gave most consistant results of biological control against late blight disease (Yang et al., 2001). Kaya et al. (2006) evaluated metabolites produced by Xenorhabdus spp against $P$. infestans. Bio-agent Steinernema feltiae was also studied against late blight both in vivo and in vitro. Yang et al. ( 2001) tested metabolites from culture broth of Xenorhabdus nematophilus isolated from nematode Steinernema caropcapsae for control late blight in potato potted plants and revealed that metabolites @ 25 and $50 \mathrm{mg} / \mathrm{l}$ found effective in reducing late blight intensity.

Potential antagonists: Many scientists worked on infection of Phytophthora infestans on potato tubers to search for micro-organism as possible antagonists to the test pathogen. Isolates of Pseudomonas spp, Burkholderia spp, Streptomyces spp and Trichoderma spp were obtained from stems, leaves, tubers and rhizoplane of potato plants. The activity of these microorganism to $\mathrm{A} 1$ and $\mathrm{A} 2$ mating type of $P$. infestans were assessed on potato leaves in moist chamber, greenhouse and in field. Reduction in late blight severity occurred with Burkholderia spp, Streptomyces spp and Pseudomonas spp applied individually or in combination (Lozoya-Saldana et al., 2006).

The impacts of potentially effective bio-control agents against late blight would enhance disease management in organic cropping system and its contribution would be of great relevance. A combination of bio-control agents with products such as neem oil could be effective to manage late blight severity (Diniz et al., 2006) and it could be another option to reduce crop losses caused by the pathogen. Among the seven potato phylloplane fungi, only three fungi viz., Fusarium spp, Trichoderma spp, Aspergillus spp showed antagonistic potential against $P$. infestans, causal agent of late blight of potato (Shailbala and Pundhir, 2007).

Systemic acquired resistance: Yan et al. (2002) suggest that induced protection elicited by both bacilli and pseudomonad PGPR strains was SA (salicylic acid) independent but ethylene and jasmonic acid dependent, whereas systemic acquired resistance elicited by the pathogen and induced local resistance by BABA ( $\beta$ amino butyric acid) were SA-dependent. BABA and phosphoric acid@2 g/l involved in systemic acquired resistance reduced late blight significantly and induced expression of defence gene in Kufri Chandramukhi (CPRI, 2014-15)

Use of endophytic organism: Some endophytic organisms were also tested against late blight of potato. Control of late blight was attempted with arbuscular mycorrhizal fungi (O' Herlihy et al., 2003). It was reported that there was reduction of disease progress rate. For potato late blight, this can be an important strategy to reduce crop losses.

Bio-fungicide: Several commercial formulations of bio-control agents have been tested for efficacy against late blight. Trichotoxin A50 is a brown liquid formulation of natural substances that can induce immunity of plants such as potato, cucumber and tomato to disease by interval spraying at 7-10 days to the plant @ 50 cc/20 lit of water (Suwan et al., 2000). Soytong and Ratanacherdchai (2005) worked on myco-fungicide against late blight of potato and results indicate that Chaetomium myco-fungicide could reduce incidence of late blight of potato caused by $P$. infestans and reduce the population in the soil with significant reduction the potato late blight.

Formulation of $T$. viride and $P$. viridicatum significantly reduced $P$. infestans sporangial germination and has potential to control potato late blight under control condition (Gupta et al., 2004). Many reports are available about antibiotic-producing microorganisms tested for bio-control capacity (Behal, 2000). However, only few antibiotics have been developed as commercial compounds in agriculture. Some of the reasons include their inconsistent efficacy in the field, their instability and the costs related to their production.

Rhizobacteria: Drenching with plant growth promoting rhizo-bacteria isolates increased the total weight of tubers per potato plants, in addition to effectively controlling late blight caused by $P$. infestans (Kim and Jeun, 2006). Beneficial effects reported by plant growth promoting rhizobacteria includes increases in a number of parameters such as germination rate, root, shoot growth, yields etc (Lucy et al., 2004). Therefore bio-control using plant growth promoting rhizobacteria represents a potentially attractive alternatives disease management approach since they are known to 
promote growth and reduce disease in crops (Jetiyanon and Kloepperm, 2002). Bacillus pumilus and Pseudomonas fluorescens induced resistance to $P$. infestans and there was reduction in zoospore formation and germination (Yang et al., 2001). In in vitro and in vivo studies, Pseudomonas, Rahnella and Serratia can lessen late blight symptoms by a combination of antibiosis and induced resistance against $P$. infestans (Daayf et al., 2003).

Essential oils: Mari et al. (2003) gave the information about the use of natural compounds derived from plants to control late blight in potato crop. The use of biological compounds extracted from plants may be an alternative to conventionally used fungicides to control phyto-pathogenic fungi, due to their being bio-active chemicals such as flavonoids, phenols, tannins, alkaloids, quinons, saponins and sterols (Burt, 2004). Biologically active compounds found in plants appear to be more adaptable, acceptable and safer than synthetic compounds and display a wealthy source of potential pathogens controlling agents (Tripathi et al., 2008).

Essential oils are oily liquids obtained from plants through fermentation, enfleurage, extraction and steam distillation (Burt, 2004). Essential oils have two prominent features i.e. low toxicity for people and environment due to their natural properties and low risk for resistance development by pathogenic microorganisms (Dafererra et al., 2000). Amini et al., (2012) reported antifungal activity of essential oil obtained from three medicinal plants i.e. Zataria multiflora, Thymus vulgaris and Thymus kotschyanus against phyto-pathogenic fungi. Even Caraway essential oil delayed the onset of late blight for about 10-14 days under field conditions (Hannukkala et al., 2002). Keskitalo et al., (2005) worked and reported that caraway oil delay the onset of disease for 14 days. The control activity of this oil is based on prevention of late blight sporangia production and growth at low oil concentration.

Plant extracts: Plant extracts are obtained by filtration, distillation and evaporation (Wang et al., 2004). The work on plant extracts with anti-oomycetes activity has been increased over the years and efficacy of plant extracts against pathogen has also been demonstrated. Several preliminary in vitro studies has been conducted in China and India (Cao et al., 2003 and Deepa et al., 2004). Six extracts from plant material (Galla chinensis, Potentilla erecta, Rheum rhabarbarum, Salviae officinalis, Sophora flavescens, and Terminalia chebula) were tested for controlling effects against the infection of $P$. infestans on detached potato leaves, seedlings and tuber slices. On detached leaves, $G$. chinensis was the best. On seedlings, R. rhabarbarum showed the best inhibiting effect (Shutong Wang et al., 2007).

One of the most effective treatments was extract of garlic cloves which at 1 or 2 percent completely inhibit the zoospore formation and colony growth of pathogen (Cao and Van Bruggen, 2001). Wang et al. (2004) reported that Inula viscosa reduced $90 \%$ late blight severity in potato plants. Extracts of Terminalia chebula and Galla chinensis were also found effective to control late blight of potato and $30 \%$ and $10 \%$ inhibition of disease were noticed respectively (Cao et al., 2004).

Ahn et al. (2005) reported that methanolic extract of galls (gall caused by an aphid, Schlechtendalia chinensis in nutgall sumac tree) reduced approximately $90 \%$ late blight severity. Extract derived from Pseudarthria viscida, Cassia tora and Catalpa ovata have also inhibited growth of $P$. infestans under laboratory condition (Kim et al., 2004; Cho et al., 2006). Extract obtained from lichens, such as Evernia prunastri, Hypogymnia physodes and Cladonia portentosa also reported as capable of inhibiting $P$. infestans in vitro (Halama and Haluwin, 2004).

Other products: Scheuerell and Mahaffee (2002) reported that combination of water based extract fermented tea and plant compost (known as compost tea) as foliar spray in potato not only improve soil fertility but also control pathogen and pests. This compost tea may be considered as one of the best option to control of late blight disease of potato (Rashidul Islam et al., 2013). Application of compost tea/organic tea extracts managed late blight of potato and several other plant disease (Al-Dahmani et al., 2005 ; Scheuerell and Mahaffee, 2006).

Host-plant resistance: Due to rapid development of new strains of Phytophthora infestans, host plant resistance appears eco-friendly and economic feasible approach for late blight management. Shailbala and Pundhir (2008) also reported that host resistance have potential to manage late blight disease of potato. In $19^{\text {th }}$ century, breeding for resistance to Phytophthora infestans was started but continued at slower rate. Njualem et al., 2001 also reported variation in resistance against late blight among potato cultivars. Resistant potato cultivars could easily destroyed by newer strains of pathogen since single gene control the resistance. Potato cultivars with high level of resistance can be helpful and allow growing even in cool season without use of fungicides. Durable or polygenic or field resistance is generally controlled by several minor genes which give slow blighting effect. Fry (1977) reported that potato cultivars with durable or polygenic resistance showed significantly less values of area under disease progress curve and low infection rates as compared to susceptible cultivars.

Jones (1998) observed that different potato cultivars shows different resistance level against late blight which can involve in management strategy. No potato cultivar reported as fully resistant/immune against late blight disease (ATTRA, 2004). Resistant cultivars show different level of resistance against various races 
of P. infestans (Popokova, 1972). Many released and improved resistant potato cultivars lost their resistance against disease but was able to tolerate the disease and gave satisfactorily yield (GLIB and CIP, 2004 a). Shtienberg et al., 1994 concluded that use of resistant cultivars can be one component to be use in late blight management for tropical condition. Shtienberg et al., 1994 also reported that compatible races of pathogen Phytophthora infestans fastly broken down race specific oligogenic resistance (CIP, 1989) in released potato cultivars and made them susceptible against late blight disease within short duration. Integration of resistant potato cultivars with improved cultural practices can lower down late blight disease (FAO, 2008).

Initially resistance gene was identified in Solanum demissum which provided base to transfer resistance gene from it and to develop resistant cultivar i.e. Kufri jyoti (having $\mathrm{R}$ gene 3.4 .7 ) for commercial cultivation in 1968. Low inoculum load and shorter late blight congenial period was important factor behind popularity of this cultivar in several part of country till date. Shekhawat (2000) reported that Solanum tuberosum subsp andigena have also been exploited for development of resistant cultivar. Kirk et al., 2001 also advanced various breeding lines showing different disease level to reduce fungicide application. Resistance gene from Solanum bulbocastanum showed broad spectrum resistance against late blight disease (Song et al., 2003). late blight resistant cultivars have capacity to delay the disease onset and further disease development so fewer fungicidal sprays on these resistant cultivars can effectively manage the disease (Agrios, 2005). Moderately resistant potato cultivars delayed onset of late blight disease by 20 days as compare to susceptible and moderately susceptible cultivars (Binyam et al., 2014 a).

Bio-technological approach: Potato is considered as poor man's food and late blight as catastrophic disease. Late blight free potato will have direct impact on people's food security and income in developing countries. Worldwide use efficiencies of land, water, nutrients and energy can greatly improve by achieving disease free potato tubers but practically it is not possible. To get disease free potato tubers, bio-technological approach against late blight can be the best option. The knowledge on molecular biology and genetics of interaction between plant and oomycetes mainly focussed on discovery of many resistance genes, numerous effector proteins and analysis of their mode of action which provide important information required for development of durable resistance (Haverkort et al., 2009). A novel approach is mainly based on cisgenic modification which depends on marker free gene pyramiding with their spatial and temporal deployment. This cisgenic modification approach with potato's own gene is societally acceptable and also results in simplification in the legislation on the use of cisgenic modifi- cation approach (Haverkort et al., 2009). So DuRPh (Durable Resistance against Phytophthora infestans) programme were made which focus on durable resistance in potato crop.

In DuRPh programme, cloning, transformation and selection of desired resistance gene ids important part of process to develop late blight resistance. The main aim of this programme is to develop cisgenic potato variety with durable resistance feature against late blight disease. Some important features of DuRPh programme includes

Genetic modification: This includes detection, isolation, cloning and transformation of gene from wild species into existing varieties through Agrobacterium tumefaciens, a bacterial vector. The plantlets regenerated from callus are screened to assess for resistance. Important point is that they should have the same phenotype as the wild variety into which resistance genes introduced.

Cisgenic approach: In this approach, natural resistance genes from plant itself or from crossable species are used and the choice of cisgenic was mainly based on availability of resistance gene in potato crop. Jochemsen, (2008) reported that this approach was ethically more acceptable to the public.

Through gene pyramiding, several resistance genes are inserted to reduce the rapid break down.

In this programme, no markers are used so variety obtained will be maker free. PCR (Polymerase Chain Reaction) techniques are used to assure that resistance gene is present in genotype show resistant against all known pathotypes of Phytophthora infestans.

In different varieties at different sites at different times, various combinations of stacked genes are deployed resulting spatial and temporal seperated deployment of resistance gene.

The start and end product during this programme is potato varieties which consist of potato genes only. In this programme, no new varieties developed and only point is that in old variety resistance gene of wild potato species were incorporated.

The exploitation of the $\mathrm{R}$ genes which is not to be homologous to previously discovered ones, is possible by protecting the intellectual property and making them available (not exclusively) to private potato breeding companies.

\section{Conclusion}

Late blight of potato is the most dreaded disease and will continue to remains as the pathogen is evolving at a fast rate and adapting to new environments and hosts. Due to highly variable nature of late blight pathogen, preventing the establishment of infection is perhaps the most interesting strategy for management of late blight. Detaining pathogen development after infection is difficult. So application of control measures can reduce the survival period as well as the 
effectiveness of the source of initial inoculum which prevent sporangia germination (germ tube formation) and/ or zoospore germination. Late blight forecasting models will help the growers in managing this serious disease. Farmers should contact their local extension office regarding disease forecasting and accordingly they can apply the preventive control measures. Use of resistant varieties along with physiological strategies for disease management can be the best option. Cultural practices for disease management always consider the first line of defense while biological control can become an integral part of management programme aimed at controlling late blight. Biotechnological approaches can help in development of durable resistance varieties. So management strategies include disease forecasting system, host plant resistance, physiological strategies, cultural control, biological control and biotechnological approach, as already discussed certainly can become an integral part in management programme aimed at controlling late blight in both conventional and organic cropping system of potato. So, alternative non-fungicidal eco-friendly control measure against late blight should be implemented under a holistic approach. As more and more information is being generated, there is a need to develop an appropriate disease management strategy based on farmer friendly information technology.

\section{REFERENCES}

Adams, S. S. and Stevenson, W. R. (1990). Water management, disease development and potato production. Am. Potato J., 67(1): 3-11

Agrios, G. N. (2005). Plant Pathology. $5^{\text {th }}$ edition. Academic Press, London, New York, 922 Pp.

Ahn, Y., Lee, H., Oh, H., Kim, H. and Lee, Y. (2005). Antifungal activity and mode of action of galla rhois-derived phenolic against phyto-pathogenic fungi. Pesticide Biochem. Physiol., 81: 105-112

Al-Dahmani, J. H., Abbasi, P. A., Sahin, F., Hoitink, H. J. and Miller, S. A. (2005). Reduction of bacterial leaf spot severity on radish, lettuce and tomato plants grown in compost amended potting mixes. Can. J. Plant Path., 27: $186-193$

Amini, M., Safaie, N., Salmani, M. J. and Shams-Bakhsh, M. (2012). Antifungal activity of three medicinal oils against some phytopathologic fungi. Trakia J. Sci., 10: 1 $-8$

Andrare-Piedra, J. L., Forbes, G. A., Shtienberg, D., Grunwald, N. J., Taipe, M.V., Hijmans, R. J. and Fry, W. E. (2005). Qualification of a plant disease simulation model: Performance of the LATEBLIGHT model across a broad range of environments. Phytopathol., 95: 14121422

Arora, R. K. (2008). Late blight an increasing threat to seed potato production in North-Western plains of India. Acta Horticulturae. 834: 201-202

Arora, R. K., Kamble, S. S. and Gangawane, L. V. (1992) Resistance to metalaxyl in $P$. infestans in Nilgiri hills of southern India. Phytophthora Newsl., 18: 8-9

Arora, R. K., Sharma, S. and Singh, B. P. (2014). Late blight disease of potato and its management. Potato J., 41(1): $16-40$

ATTRA (Appropriate Technology Transfer to Rural Area). (2004). Organic alternatives for late blight control in potatoes. National Sustainable Agriculture Information Service.

Behal, V. (2000). Bio-active products from Streptomyces. Adv. Appl. Microbiol., 47: 113-157

Benno, Kleinhenz., Kristina, F., Joachim, K. and Dietmar, R. (2007). SIMBLIGHT1-A new model to predict first occurrence of potato late blight. EPPO Bull., 37: 339343

Berg, A. (1926). Tomato late blight and its relation to late blight of potato. West Virgiana Agric. Exp. Stn. Tech. Bull., 205: 1-31

Bhattacharyya, S. K. and Singh, B. P. (1986). Durable resistance against the potato late blight in India. Indian Phytopath., 39: 615-619

Bhattacharyya, S. K., Raj, S., Singh, D. S., Khanna, R. and Sharma, S. R. (1983). Forecasting late blight of potato in Indian hills. In: B. B. Nagaich et al. (eds.) Potato in developing countries. Indian Potato Association. CPRI. Shimla, Pp 20-23

Bhattacharyya, S. K., Singh, B. P., Sharma, V. C., Bambawal, O. M., Arora, R. K. and Singh, P. H. (1990). Mode of survival and source of primary inoculum of late blight of potato. Intern. J. Tropic. Pl. Dis., 8: 78-88

Binyam, T., Hussen, T. and Tsegaw, T. (2014a). Efficacy of reduced dose of fungicide sprays in the management of late blight (Phytophthora infestans) disease on selected potato (Solanum tuberosum L.) varieties Haramaya, Eastern Ethiopia. J. of Biology, Agriculture and Healthcare, 4(20): 46-52

Bourke, P. M. A. (1953). Potato blight and weather a fresh approach. Technical Note No-12. Irish Meteorological Service.

Bourke, P. M. A. (1970). Use of weather information in the prediction of plant disease epiphytotics. Ann. Rev. Phytopathol., 8: 345-370

Bouws, H. and Finckh, M. R. (2008). Growing potatoes in narrow strips perpendicular to wind and separated by non -potatoes. Plant Path., 52(5): 916-927

Bruhn, J. A. and Fry, W. E. (1981). Analysis of potato late blight epidemiology by simulation modeling. Phytopathol., 71: 612-616

Bruhn, J. A. and Fry, W. E. (1982a). A statistical model of fungicide deposition on potato foliage. Phytopathol.,73:1301-1305

Bruhn, J. A. and Fry, W. E. (1982b). A mathematical model of the spatial and temporal dynamics of chlorothalonil residues on potato foliage. Phytopathol., 72: 1306-1312

Burt, S. (2004). Essential oils: Their antibacterial properties and potential applications in foods- A review. Intern. $J$. Food Microbiol., 94: 223- 253

Cao, K. Q. and Van Bruggen, A. H. C. (2001). Inhibitory efficacy of several plant extracts and plant products on Phytophthora infestans. J. Agric. Univ. Hebei., 24: 9199

Cao, K. Q., Wang, S. T., Forrer, H. R. and Fried, P. M. (2004). Inhibitory effects of chineese medicinal plants against Phytophthora infestans on potatoes. Regional workshop on potato late blight for east and south-east Asia and the Pacific, International Potato Center and 
Ministry of Agriculture and Irrigation, Myanmar, Yezin Agricultural University. Pp 45-53

Cao, K. Q., Wang, S. T., Kessler, P., Fried, P. M. and Forrer, H. R. (2003). Potato late blight: A new approach for an outdoor screening of substitutes for copper fungicides. Krautfaulebekampfung im Bio-Kartoffelanbau ohne Kupfer? Agrarforschung., 10: 182

Cho, J. Y., Kim, H. Y., Choi, G. J., Jang, K. S., Lim, H. K., Lim, C. H., Cho, K. Y. and Kim, J. C. (2006). Dehydroalpha-lapachone isolated from Catalpa ovata stems: Activity against plant pathogenic fungi. Pest Management Sci., 62: 414-41

CIP (International Potato Center). (1989). Fungal diseases of potato. Report of planning conference on fungal diseases of the potato. CIP, Lima, Peru, $21^{\text {th }}-25^{\text {th }}$ September, Pp 216

CPRI. (2014-15). Annual Progress Report. Central Potato Research Institute, Shimla, Pp. 198

CPRI. (1981). Annual Scientific Report. Central Potato Research Institute, Shimla, Pp. 61-64

CPRI. (1987). Annual Scientific Report. Central Potato Research Institute, Shimla, Pp. 96-109

CPRI. (1999). Annual Scientific Report. Central Potato Research Institute, Shimla, Pp 70-77

CPRI. (2013). Annual Progress Report. Central Potato Research Institute, Shimla, Pp 158

Cristinzio, G., Testa, A. and Pugliano, P. (1998). Races of Phytophthora infestans in Italy. Informatore Fitopatol., 48(9): 49-51

Daayf, F. and Platt, H. W. (2000). Changes in metalaxyl resistance among glucose phosphate isomerase genotypes of Phytophthora infestans in Canada during 19971998. Am. J. Potato Res., 77: 311-318

Daayf, F., Adam, L. and Fernando, W .G. D. (2003). Comparative screening of bacteria for biological control of potato late blight (strain US-8), using in vitro, detachedleaves, and whole-plant testing systems. Can. J. Plant Pathol., 25: 276-284

Daayf, F., Platt, H. W., Mahuku, G. and Peters, R. D. (2001). Relationships between RAPDs, Gpi-allozyme patterns, mating types and resistance to metalaxyl of Phytophthora infestans in Canada in 1997. Am. J. Potato Res., 78: 129-139

Dafererra, D. J., Ziogas, B. N. and Polissiou, M. G. (2000). GC-MS analysis of essential oils from some greek aromatic plants and their fungitoxicity on Penicillium digitatum. J. Agric. Food Chem., 48: 2576-2581

De Bary, A. (1876). Research into the nature, the potato fungus Phytophthora infestans. J.R. Agric. Sco. Eng., 12: 239-269

Deepa, M. A., Bai, V. N. and Basker, S. (2004). Antifungal properties of Pseudarthria viscida. Fitoterapia., 75: 581584

Deshraj., Garg, V. K. and Singh, S. (1997). Effect of date of planting and haulms killing on total yield and seed size tubers in potato cultivar K. Jyoti. J. Indian Potato Assoc., 24(1-2): 71-73

Dick, M. W. (2001). Stramenopilous fungus. Kluwar, Hingham MA.

Diniz, L. P., Maffia, L. A., Dhingra, O. D., Casali, V. W. D., Santos, R. H. S. and Mizubuti, E. S. G. (2006). Avaliacao de produtos alternativos para-controle da requeima do tomateiro. Fitopatologia Brasileira, 31: 171
$-179$

Dutt, B. L. (1964). Late blight of potato in India. In: Distribution and blight period. Indian Potato J., 6: 34-41

Dutt, B. L. (1965). Late blight of potato in India. In: Distribution and incidence of physiologic races. Indian Potato $J ., 7: 23-28$

Eduardo, S. G. M., Valdir, L. J. and Gregory, A. F. (2007). Management of late blight with Alternative products. Pest Tech., 1(2): 106-116

FAO (Food and Agriculture Organization). (2008). Potato World: Africa-International year of the potato 2008. http://www.potato2008.org/en/world/africa.html. Accessed at: 12/5/2014

Fernandez-Pavia, S. P., Grunwald, N. J., Diaz-Valasis, M., Cadena-Hinojosa, M. and Fry, W. E. (2004). Soil-borne oospores of Phytophthora infestans in Central Mexico survive winter fallow and infect potato plants in the field. Plant Dis., 88: 29-33

Ferrandino, F. J. (1989). Spatial and temporal variation of a defoliating plant disease and reduction in yield. Agricultural and Forest Meteorology, 47: 273-289

Forbes, G. A. and Landeo, J. A. (2006). late blight. In : (Gopal, J.P.K.S.M. ed.) Handbook of potato production, improvement and post harvest management, Haworth Press Inc., Binghamton, New York, Pp. 279-320

Forbes, G. A., Fry, W. E., Andrade Piedra, J. L. and Shtienberg, D. (2008). Integrated management of disease caused by fungi, phytoplasma and bacteria. (A. Ciancio and K.G. Mukherji eds). Springer. Pp. 161-177

Forrer, H. R., Gujer, H. O. and Fried, P. M. (1993). PhytoPRE-A comprehensive information and decision support system for late blight in potatoes. In: Workshop on computer based decision support system (DSS) in crop protection. Italy.

Forster, H., Coffey, M.D., Elwood, H. and Sagin, M.L. (1990). Sequence analysis of the small sub-unit ribsomal RNAs of the zoosporic fungi and implication for fungal evolution. Mycologia., 82: 306-312

Forsund, E. (1983). Late blight forecasting in Norway 19571980. EPPO Bull., 13: 255-258

Fry, W. E. (1977). Integrated control of late blight-effects of polygenic resistance and techniques of timing fungicide applications. Phytopathol., 67: 415-420

Fry, W. E. (1998). Vegetable crops: late blight potatoes and tomatoes. Cornell University Cooperative Extension. New York State. USA. Available on: Page: 726.20 Date 7-1998). (http://vegetablemdonline.ppath.cornell.edu/ factsheets/Potato_L ateBlt.htm)

Fry, W. E., Apple, A. E. and Bruhn, J. A. (1983). Evaluation of potato late blight forecast modified to incorporate host resistance and fungicide weathering. Phytopathol., 73: 1054-1059

Fry, W. E., Small, I. M. and Danies, G. (2015). Epidemiology and decision support system. In: $3^{\text {rd }}$ International symposium on Phytophthora: Taxonomy, genomics, pathogenicity, resistance and disease management. $9^{\text {th }}$ $12^{\text {th }}$ September, 2015. Bengaluru, India, Pp. 31

Fry, W. E., Smart, C. D., Monti, L., Leone, A., Struik, P. C., Hide, G. A. and Storey, R. M. J. (1999). The return of Phytophthora infestans, a potato pathogen that just won't quit. In: (Struik and Hide eds). Proceedings of the $14^{\text {th }}$ Triennial conference of the European association for potato research, Sorrento, Italy $2^{\text {nd }}-7^{\text {th }}$ May, Extra edition 
42: $279-82$

Fry, W. E., Thurston, H. D. and Stevenson, W. R. (2001). late blight. In : Stevenson W.R., Loria, R., Franc G.D., Weingartner, D.P. (eds.) Compendium of potato diseases ( $2^{\text {nd }}$ edn), The American Phytopathological Society, St Paul, USA, Pp 22-23

Garg, V. K., Deshraj. and Singh, S. (1999). Influence of date of planting and haulm killing on the yield of seed sized tubers in Shimla hills. J. Indian Potato Assoc., 26(1-2): 1 $-6$

Garrett, K. A. and Dendy, S. P. (2001). Cultural practices in potato late blight management. In: Complementing resistance to late blight (Phytophthora infestans) in the Andes (Fernandez- Northcoted, N. (ed.). Proceedings of GILB Latin American workshop I, $13^{\text {th }}-16^{\text {th }}$ February, 2001, Cochabamba, Bolivia. Pp. 107-113

Ghorbani, R., Wilcockson, S. and Leifert, C. (2005). Alternative treatments for late blight control in organic potato: Antagonistic micro-organism and compost extracts for activity against Phytophthora infestans. Potato Res. 48: $181-189$

Giddings, N. J. and Berg, A. (1919). A comparison of the late blight of tomato and potato: A preliminary report. Phytopathol., 9: 209-10

GILB (Global Initiative on Late Blight) and CIP (International Potato Center). (2004a). Ethiopia: Potato production areas and average yields. Available on: Accessed at 29/3/2014 http://gilb.cip.cgiar.org/ countryprofiles/ africa/ethiopia/.

Govindakrishnan, P. M., Singh, B. P., Ahmad, I., Rawat, S. and Sharma, S. (2015). Indoblightcast-A simple generic DSS for late blight. In: $3^{\text {rd }}$ international symposium on Phytophthora: Taxonomy, genomics, pathogenicity, resistance and disease management. $9^{\text {th }}-12^{\text {th }}$ September, 2015. Bengaluru, India, Pp 32

Guo, J., Lee, T. V., Qu, D. Y., Yao, Y. Q., Gong, X. F., Liang, D. L., Xie, K. Y., Wang, X. W. and Grovers, F. (2009). Phytophthora infestans isolates from northern China show high virulence diversity but low genotypic diversity. Plant Biol., 11(1): 57-67

Gupta, H., Singh, B. P. and Jitendra, M. (2004). Bio-control of late blight of potato. Potato J., 31: 39-42

Gutsche, V. (1993). PROGEB - A model aided forecasting service for pest management in cereals and potatoes. EPPO Bull., 23: 577-581

Halama, P. and Haluwin, V. (2004). Antifungal activity of lichen extracts and lichenic acids. Biocontrol., 49: 95107

Haldar, K., Kamoun, S., Hiller, N. L., Bhattacharje, S. and Van Ooij, V. (2006). Common infection strategies of pathogenic eukaryotes. Nature Review Microbiol., 4: 922-931

Hannukkala, A., Keskitalo, M., Laamanen, J. and Rastas, M. (2002). Control of potato late blight with caraway and dill extracts. In: (H.T.A.M. Schepers and C.E. Westerdijk, eds). Proceedings of the $6^{\text {th }}$ workshop of a European network for development of an integrated control strategy of potato late blight. Edinburgh, Scotland, $26^{\text {th }}$ $30^{\text {th }}$ September 2001. PPO-Special Report, 8: 279-280

Haverkort, A. J., Struik, P. C., Visser, R. G. F. and Jacobsen, E. (2009). Applied biotechnology to combat late blight in potato caused by Phytophthora infestans. Potato Res., 52: $249-264$

Henshall, W. R., Shtienberg, D. and Beresford, R. M.
(2006). A new potato late blight disease prediction model and its comparison with two previous models. New Zealand Plant Protec., 59: 150-154

Hohl, H. R. and Iselin, K. (1984). Strains of Phytophthora infestans from Switzerland with A2 mating type behaviour. Trans. Br. Mycol. Soc., 83: 529-30

Hospers-Brands, A. J. T. M., Ghorbani, R., Bremer, E., Bain, R., Litterick, A., Haldar, F., Leifert, C. and Wilcockson, S. J. (2008). Effect of pre-sprouting, planting dates, plant population and configuration of late blight and yield of organic potato crop grown with different cultivars. Potato Res., 51: 131-150

Imas, P. and Bansal, S. K.(1999). Potassium and integrated nutrient management in potato. In: Global conference on potato. $6^{\text {th }}-11^{\text {th }}$ November, 1999, New Delhi, India.

Jetiyanon, K. and Kloepperm, J. W. (2002). Mixtures of plant growth promoting rhizobacteria for induction of systemic resistance against multiple plant diseases. Biol. Control., 24: $285-291$

Jochemsen, H. (2008). An ethical assessment of cisgenesis in breeding late blight resistant potato. Potato Res., 51: 5973.

Johnson, D. A., Alldredge, J. R. and Vakoch, D. L. (1996). Potato late blight forecasting models for the semi-arid environment of South-Central Washington. Phytopathol., 86: $480-484$

Jones, G. D. (1998). The epidemiology of plant diseases. $3^{\text {rd }}$ edition. Kluwer Academic Publishes. London. Pp. 371388

Kamoun, S. and Nusbaum, C. (2009). Genomic sequence and analysis of the Irish potato famine pathogen Phytophthora infestans. Nature., 461: 393-398

Kamoun, S. and Smart, C. D. (2005). Late blight of potato and tomato in genomics era. Plant Dis., 89: 692-699

Kassa, B. and Sommartya, T. (2006). Effect of intercropping of potato late blight Phytophthora infestans (Mont.) de Bary development and potato tuber yield in Ethiopia. Kasetsar J., (Nat. Sci.). 40: 914-924

Kaya, H. K., Aguillera, M. M., Alumai, A., Choo, H. Y., Dela Torre, M., Fodor, A., Ganguly, S., Hazir, S., Lakatos, T., Pye, A., Wilson, M., Yamanaka, S., Yang, H. and Ehlers, R. (2006). Status of entomopathogenic nematodes and their symbiotic bacteria from selected countries or regions of the world. Bio. Control., 38: 134-155

Keane, T. (1995). Potato blight warning practice in Ireland. In: Phytophthora 150. (Dowley, L.W et al eds), Boole Press Ltd. Dublin. Pp. 191-200

Keskitalo, M., Fabritius, A. L., Hakala, K., Hannukkala, A., Ketoja, E., Lehtinen, A., Mikkonen, P. and Vuorema, A. (2005). Control of potato late blight by caraway oil in organic farming. In: Nordiska Jordbruksforskares Frening NJF-Seminar 369 on organic farming for a new millennium - status and future challenges. Pp. 77-79

Kim, H. J. and Jeun, Y. C. (2006). Resistance induction and enhanced tuber production by pre-inoculation with bacterial strains in potato plants against Phytophthora in festans. Mycobiol., 34: 67-72

Kim, Y., Lee, C., Kim, H. and Lee, H. (2004). Anthraquinones isolated from Cassia tora (leguminosae) seed show an antifungal properties against Phytopathogenic fungi. J. Agricul. and Food Chem., 52: 6096-6100

Kirk, K. K., Felcher, K. J., Douches, D. S., Coombs, J., Stein, J. M., Baker, K. M. and Hammerschmidth, R. (2001). Effect of host resistance and reduced rates and frequen- 
cies of fungicide application to control potato late blight. Plant Dis., 85(10): 1113-1118

Kirk, W. (2009). Potato late blight alert for the mid west. Field crop advisory team alert. Current News Articles.

Kirk, W. W., Samen, F., Abu-E. L., Thumbalam, P., Wharton, P., Douehes, D., Thrill, C. A. and Thompson, A. (2009). Impact of different US genotypes of Phytophthora infestans on potato seed tuber rot and plant emergence in a range of cultivars and advanced breeding lines. $\mathrm{Po}$ tato Res., 52: 121-140

Kirk, W., Wharton, P., Hammerschmidt, R., Abu-el Samen, F. and Douches, D. (2013). Late blight. Michigan state university extension bulletin E-2945. East Lansing, MI. Available on: http://www.potatodiseases.org/ lateblight.html

Krause, R.A., Massie, L.B. and Hyre, R.A. (1975). BLITECAST: A computerized forecast of potato late blight. Plant Dis. Reptr., 59: 95-98

Kumaon, S. (2001). Non-host resistance to Phytophthora: Novel prospects for a classical problem. Curr. Opin. Plant Biol., 4: 295-300

Lamsal, K., Kim, S. W., Kim, Y. S. and Lee, Y. S. (2013). Bio-control of late blight and plant growth promotion in tomato using rhizobacterial isolates. J. Microbiol. Biotech., 23: 885-892

Lee, S. K., Kelley, B. S., Damasceno, C. M. B., St. John, B., Kim, B., Kim, B. D. and Rose, J. K. C. (2006). A functional screen to characterize the secretomes of eukaryotic pathogens and their hosts in planta. Molecular Plant Microbe Interactions, 19: 1368-1377

Lehtinen, A. and Hannukkala, A. (2004). Oospores of Phytophthora infestans in soil provide an important new source of primary inoculum in Finland. Agricultural and Food Science in Finland, 13: 399-410

Lozoya-Saldana, H., Coyote-Palma, M. H., Ferrera-Cerrato, R. and Lara-Hernaadez, M. E. (2006). Microbial antagonism against Phytophthora infestans (Mont) de Bary. Agrociencia, 40: 491-499

Lucy, M., Reed, E. and Glick, B. R. (2004). Application for free living plant growth promoting rhizobacteria. Antonie Van Leeuwenhoek, 86: 1-25.

Mari, M., Bertolini, P. and Pratella, G. (2003). Nonconventional methods for the control of post-harvest pear diseases. J. Applied Microbiol., 94: 761-766

Marschner, H. (1995). Mineral nutrition on higher plants. $2^{\text {nd }}$ Edition, Academic Press, London.

Martin, A. D., Gary, A.S., Neil, C.G., Arthur, H. L. and Duane, P. (1994). Leaf blight diseases of potato. North Dakota State University Agriculture and University Extension.

Rashidul Islam, M., Mandal, C., Hossain, I. and Meah, B. M. (2013). Organic management: An alternative to control late blight of potato and tomato caused by Phytophthora infestans. Int. J. Theoretical and Applied Sci., 5: 32-42

Minogue, K. P. and Fry, W. E. (1983). Models for the spreads of disease: Some experimental results. Phytopathol., 73: 1173-1176

Njualem, D. K., Demo, P., Mendoza, H.A., Koi, J. T. and Nana, S. F. (2001). Reaction of some potato genotypes to late blight in Cameroon. African Crop Sci. J., 1(1): 209213

O'herlihy, E. A., Duffy, E. M. and Cassells, A. C. (2003). The effects of arbuscular mycorrhizal fungi and chitosan sprays on yield and late blight resistance in potato crops from micro-plants. Folia Geobotanica, 38: 201-207

Pande, A., Jagyasi, B. G. and Choudhuri, R. (2009). Late blight forecast using mobile phone based agro advisory system. (Choudhary et al eds). Springer-Verlag Berlin Heidelberg. Pp. 609-614

Paysour, R. E. and Fry, W. E. (1983). Inter plot interference: A model for planning field experiments with aerially disseminated pathogen. Phytopathol., 73: 1014-1020

Phadtare, S. G., Dutt, B. L., Dhingra, M. K. and Raj, S. (1973). A new race of Phytophthora infestans from Shimla hills. Indian Phytopath., 26: 589-590

Popokova, K.V. (1972). Late blight of potato in Moscow. Review of crop production research in Ethiopia. In: (Tsedeke Abate ed.). Proceedings of the I ${ }^{\text {st }}$ Ethiopian crop protection symposium. Institute of Agricultural Research. Addis Ababa. Ethiopia.

Rivera-Pena, A. (1995). Phytophthora infestans 150. European association for potato research, Pathology section conference, Durbin, Ireland: 116-121

Scheuerell, S. and Mahaffee, W. (2002). Compost tea: Principles and prospects for plant disease control. Compost Science and Utilization, 10: 313-338.

Scheuerell, S. J. and Mahaffee, W. F. (2006). Variability associated with suppression of gray mould (Botrytis cinerea) on geranium by foliar applications of nonaerated and aerated compost teas. Plant Dis., 90: 12011208

Schick, R. (1932). Uber das verhalten von Solanum demissum, Solanum tuberosum und ihren Basterden gegunber verschiedenen Herkunjten von Phytophthora infestans. Zuechter 4: 233-237

Shailbala and Pundhir, V. S. (2007). Effect of date of planting and fungicidal sprays on potato phylloplane fungi. Ann. Pl. Protec. Sci., 15(2): 434-437

Shailbala and Pundhir, V. S. (2007). Effect of potato mustard intercropping on late blight severity, yield and economics of potato. Plant Dis. Res., 22(1): 67-69

Shailbala and Pundhir, V. S. (2008). Efficacy of fungicides and bio-agents against late blight severity, infection rate and tuber yield of potato. J. Pl. Dis. Sci., 3(1): 4-8

Shailbala and Pundhir, V. S. (2008). Integration of host resistance and fungicides for management of late blight of potato. Potato J., 35(1-2): 97-99

Shailbala and V. S. Pundhir. (2006). Effect of date of planting on late blight severity and yield of potato. Ann. Pl. Protec. Sci., 14: 404-406

Shanmugam, V. (2001). Epidemiology and management of late blight of potato. M.Sc. Thesis, G.B.P.U.A.T., Pantnagar. Pp. 83

Sharma, K. K. (2000). Influence of meteorological factors on potato late blight development in North-Western plains of India. J. Indian Potato Assoc., 27: 1-3

Shekhawat, G. S. (2000). Management of potato diseases through host resistance. J. Mycol. Pl. Pathol., 30(2): 143 $-150$

Shinners, C. T., Bains, P., McLaren, D. and Thomson, J. (2003). Commercial potato production - disease management. Guide to commercial potato production prairies. Western Potato Council. Available on: http:// www.gov.mb.ca/agriculture//crops/potatoes/bda04s07

Shtienberg, D., Raposo, R., Bergerson, S. N., Legard, D. E., Dyer, A. T. and Fry, W. E. (1994). Inoculation of cultivar resistance reduced spray strategy to suppress early and late blight on potato. Plant Dis., 78: 23- 26 
Shutong, Wong., Tongle, Hu., Fengqiao, Z., Forrer, H.R. and Keqiang, Cao. (2007). Screening for plant extracts to control potato late blight. Frontiers Agric. China, 1: 4346

Singh P. H., Singh, B. P. and Bhat, N. M. (2005). Mating types, metalaxyl resistance and racial complexicity in Phytophthora infestans population-present status. Potato J., 32: $177-178$

Singh, B. P. (2000). Status of late blight in sub tropics. In: Potato global research and development (Khurana, S. M. P., Shekhawat, G. S., Singh, B. P. and Pandey, S. K. eds.). Indian Potato Association. CPRI, Shimla, H.P. India. Pp. 525-533

Singh, B. P., Gupta, H., Roy, S. and Shekhawat, G. S. (1997). Ploidy status and its role in aggressiveness of Phytophthora infestans. Abstracts (518-006). Indian Phytopathological Society- Golden Jubilee International Conference, $10^{\text {th }}-15^{\text {th }}$ November, 1997, New Delhi.

Singh, B. P., Islam Ahmed., Sharma, V. C. and Shekhawat, G. S. (2000). JHULSACAST: A computerized forecast of potato late blight in Western Uttar Pradesh. J. Indian Potato Assoc., 27: 25-34

Singh, B. P., Roy, S. and Bhattacharyya, S. K. (1994) Occurrence of A2 mating type of Phytophthora infestans in India. Potato Res., 37: 227-231

Smith, L. P. (1956). Potato blight forecasting by $90 \%$ humidity criteria. Plant Path., 5: 83-87

Song, J., Bradeen, J. M., Naess, S. K., Raasch, J. A., Wielgus, S. M., Haberlach, G. T., Liu, J., Kuang, H., Phillips, S. A., Buell, C. R., Helgeson, J. P. and Jang, J. (2003). Gene RB cloned from Solanum bulbocastanum confers broad spectrum resistance to potato late blight. Proceeding of the National Academy of Sciences of U.S.A., 100(16): 9128-9133

Soytong, K. and Ratanacherdchai, R . (2005). Application of mycofungicide to control late blight of potato. J. Agricultural Technology, 1: 19-32

Struik, P. C. (2010). Can physiology help us to combat late blight in Potato? Potato Res., 53: 277-287

Struik, P. C. and Wiersema, S. G. (1999). Seed potato technology. Wageningen Pers, Wageningen.

Sujkowski, L. S., Goodwin, S. B., Dyer, A. T. and Fry, W. E. (1994). Increased genotypic diversity via migration and possible occurrence of sexual reproduction of Phytophthora infestans in Poland. Phytopathol., 84: 201-207

Sundaresha, S., Kumar, S., Singh, B. P., Jeevalatha, A., Rawat, S., Mahota, A.K. and Sharma, T. R. (2015). Comparative genome analysis of Irish famine pathogen with Indian Phytophthora infestans isolate. In: $3^{\text {rd }}$ International symposium on Phytophthora: Taxonomy, genomics, pathogenicity, resistance and disease management. $9^{\text {th }}-12^{\text {th }}$ September, 2015. Bengaluru, India, Pp. 24

Suwan, S., Isobe, M., Kanokmedhakul, S., Lourit, N., Kanokmedhakul, K., Soytong, K. and Koga, K. (2000). Elucidation of high micro-heterogeneity of an acidicneutral trichotoxin mixture from Trichoderma harzianum by electrospray ionization quadrupole time-offlight mass spectrometry. J. Mass Spectrometry, 35: 1438-1451

Tian, M., Win, J., Song, J., Van Der Hoorn, R., Van Der Knaap, E. and Kamoun, S. (2007). A Phytophthora infestans cystatin-like protein targets a novel tomato papain like apoplastic protease. Plant Physio., 143: $364-$
377.

Tripathi, M., Dubey, N. K. and Shukla, A. K. (2008). Use of some essential oils as post-harvest botanical fungicides in the management of grey mould of grapes caused by $\mathrm{Bo}$ trytis cinerea. World J. Microbiol. Biotechnol., 24: 3946

Tsedaley, B. (2014). Late blight of potato (Phytophthora infestans) biology, economic importance and its management approaches. J. Biology Agriculture and Healthcare. 25(4): $215-225$

Turner, R.S. (2005). After the famine: Plant pathology, Phytophthora infestans and the late blight of potatoes, 1845 1960. Historical Studies in the Physical and Biological Sciences., 35(2): 341-370

Ullrich, J. and Schrodter, H. (1966). Das Problem der vorhersage des aufretens derKartoffelkrautfaule (Phytophthora infestans) und die moglichkeit seiner losung durch eine negative prognose. Nachrichtenblatt Dt. Pflanzenschutzdienst (Braunschweig). 18: 33-40

Van Everdingen, E. (1926). Hetverband tusschen de weergesteldhied en de aarolppelziekte, Phytopthora in festans (the relation between weather conditions and potato blight, Phytophthora infestans) Tijdschr. Plantenziekten, 32: 129-140

Van Oijen, M. (1992). Selection and use of a mathematical model to evaluate components of resistance to Phytophthora infestans in potato. Netherland J. Plant Path., 98: 192-202

Visker, M. H. P. W., Heilersig, H. J. B., Kodde, L. P., Van de Weg, W. E., Voorrips, R. E., Struik, P. C. and Colon, L. T. (2005). Genetic linkage of QTLs for late blight resistance and foliage maturity type in six related potato progenies. Euphytica, 143:189-199

Visker, M. H. P. W., Keizer, L. C. P., Budding, D. J., Van Loon, L. C., Colon, L. T. and Struik, P. C. (2003b). Leaf position prevails over plant age and leaf age in reflecting resistance to late blight in potato. Phytopathol., 93:666674

Visker, M. H. P. W., Van Raaij, H. M. G., Keizer, L. C. P., Struik, P. C. and Colon, L. T. (2004). Correlation between late blight resistance and foliage maturity type in potato. Euphytica, 137: 311-323

Visker, M. H.P.W., Keizer, L. C. P., Van Eck, H. J., Jacobsen, E., Colon, L.T. and Struik, P. C. (2003a). Can the QTL for late blight resistance on potato chromosome 5 be attributed to foliage maturity type? Theor. Appl. Gen., 106: 317-325

Waggoner, P. E. (1968). Weather and rise and fall of fungi. (Lowry, W.P eds). Oregon State, Corvallis. USA. Pp. 4566

Wallin, J. R. (1962). Summary of recent progress in predicting late blight epidemics in United States and Canada. Am. Potato J., 39: 306-312

Wang, W., Daniel, B. and Cohen, Y. (2004). Control of plant diseases by extracts of Inula viscosa. Phytopathol., 94: 1042-1047

Wharton, P. S., Kirk, W. W., Baker, K. M. and Duynslager, L. (2008). A web-based interactive system for risk management of potato late blight in Michigan. Computers and Electronics in Agriculture. 61: 136-148

Widmark, Anna-Karin. (2010). The late blight pathogen, Phytophthora infestans: Interaction with the potato plant and inoculum sources. Thesis. Swedish University of 
Shailbala and Amarendra Kumar / J. Appl. \& Nat. Sci. 9 (2): 821 - 835 (2017)

Agricultural Sciences, Uppsala. 67 Pp.

Yan, Z., Reddy, M. S., Ryu, C. M., Mcinroy, J. A., Wilson, M. and Kloepper, J. W. (2002). Induced systemic protection against tomato late blight elicited by plant growthpromoting rhizobacteria.
$1329-1333$

Yang, X., Zhang, Z., Yang, H. and Jian, H. (2001). Inhibition of metabolites from Xenorhabdus nematophilus against Phytophthora infestans. J. Hebei Agric. Univ., 24: $65-68$ 